UDC: $811.111 .42 ' 373.49 \quad$ https://doi.org/10.22190/JTESAP1904453T

\title{
EUPHEMIZATION AS PART OF RUSSIAN MEDIA OPPOSITION DISCOURSE
}

\author{
Alla Teplyashina, Vadim Golubev \\ St. Petersburg State University, Russia \\ E-Mail: v.golubev@spbu.ru
}

\begin{abstract}
Opposition discourse does not have a long history or established traditions in Russia as it does in the West where it has long become an integral part of political culture and plays a special role in modern mass communications. This paper raises the problem of risks associated with the danger of critical journalism being branded extremism on the one hand and violating the law prohibiting journalists using vocabulary not part of the Russian literary standard, on the other. It presents the results of content analysis of media texts that use a variety of expressive means of veiling sharp criticism of Russian government and mitigating emotions such as euphemisms. Considerable attention is paid to queering as an aspect of the verbal picture of an anti-world. A case study of Novaya Gazeta, the most consistent critic of Russian government, illustrates the impact recent legislation on extremism and the use of the Russian language has had on journalism in Russia and examines the ways opposition media have employed to comply with the regulations.
\end{abstract}

Key words: extremism, opposition discourse, euphemisms, comic effect

\section{INTRODUCTION}

There are several legal constraints that affect the work of Russian journalists today. This paper discusses how journalists, who choose to criticize Russian authorities comply with the requirements of national legislation concerning extremism and the use of substandard language.

In accordance with the amendments of November 23, 2015 to Federal Law No. 114 of July 25, 2002 on countering extremist activities extremism is defined as:

- forcibly changing the foundations of the constitutional system and violating the integrity of the Russian Federation;

- public justification of terrorism and other terrorist activities;

- incitement to social, racial, national or religious hatred;

- propaganda of exclusivity, superiority or inferiority of a person on the basis of their social, racial, national, religious or linguistic affiliation or attitude to religion;

- violation of the rights, freedoms and legitimate interests of a person and a citizen depending on their social, racial, national, religious or linguistic affiliation or attitude to religion; 
- hindering citizens from exercising their voting rights and the right to participate in a referendum or violating the secrecy of the vote, coupled with violence or the threat of its use;

- obstruction of the legitimate activities of state bodies, local governments, election commissions, public and religious associations or other organizations, combined with violence or the threat of its use;

- commission of crimes for the reasons specified in paragraph "e" of Part 1 of Article 53 of the Criminal Code of the Russian Federation;

- propaganda and public demonstration of Nazi paraphernalia or symbols, or paraphernalia or symbols similar to Nazi paraphernalia or symbols to a degree of confusion, or public demonstration of paraphernalia or symbols of extremist organizations;

- public calls for the implementation of these acts or the mass distribution of knowingly extremist materials, as well as their manufacture or storage for mass distribution;

- publicly known false accusation of a person holding a public office of the Russian Federation or a public office of a constituent entity of the Russian Federation of having committed the offenses specified in this article and constituting a crime during the performance of their official duties;

- organization and preparation of these acts, as well as incitement to their implementation;

- financing of these acts or other assistance in their organization, preparation and implementation, including by providing training, printing and material and technical facilities, telephone and other types of communications or the provision of information services (Garant 2019a). As we can see, the concept of extremism is defined quite broadly giving room for their flexible enforcement. Once criticism of a government official or government body is identified as false legal responsibility follows.

On March 8, 2015 Article 11 related to the responsibility for the distribution of extremist materials was amended to read:

"The distribution of extremist materials, as well as their production or storage for distribution, is prohibited on the territory of the Russian Federation. In cases provided for by the legislation of the Russian Federation, the production, storage or distribution of extremist materials is an offense and entails liability.

Information materials are recognized as extremist by the federal court at the place of their discovery, distribution or location of the organization that carried out the production of such materials, on the basis of a statement by the prosecutor or in the proceedings of the relevant administrative case, civil, administrative or criminal case.

Simultaneously with the decision to declare information materials extremist, a decision is made on their confiscation.

A copy of the final decision on recognition of information materials as extremist is sent by the court to the federal state registration authority within three days.

The federal state registration body, on the basis of a court decision on the recognition of information materials as extremist within thirty days, makes them on the federal list of extremist materials" (Garant 2019b).

Opposition discourse is a sphere of communicative conflict between the media and government. The inevitable consequence of this conflict is the risk-taking nature of the discourse. As we see from the above provisions, problems associated with critical 
statements may have legal implications both for authors of the text and for the media outlet as a whole. Linguistic expertise may see in a journalistic piece signs of defamatory information or personal insults. Thus, the author can be considered to have humiliated the honor and dignity of the person they criticized. If this person is a government official such criticism can be regarded extremist.

If the author of the text uses vocabulary marked in linguistic dictionaries as rude, vernacular or slang, they may be liable for violating another piece of legislation - one that regulates the use of Russian as a state language.

On July 5, 2014, amendments to Law 53 on the state language of the Russian Federation were adopted. They addressed the issue of balance between expressive vocabulary and profanity. According to Article 1, when using the Russian language as the state language of the Russian Federation, it is not allowed to use words and expressions that do not correspond to the norms of the modern Russian literary language (including foul language), with the exception of foreign words that do not have commonly used analogues in the Russian language (Garant 2019c).

To meet the above regulations the media had to change their editorial policies and journalists turned to euphemisms accompanied a wide spectrum of comical techniques including wordplay, irony, sarcasm, and intertextuality.

The study, the results of which are presented in this article, was focused on the 20182019 editorial content of the Russian national newspaper Novaya Gazeta. Novaya Gazeta positions itself as an opposition publication. This implies not only addressing difficult topics and their interpretation for the audience, but also the use of invective vocabulary, one of the subgroups of which is profanity. Since any use of profanity in public has been banned since 2014 it calls for euphemisms to replace substandard vocabulary. Sixty texts of political commentary containing euphemisms were selected. The texts were thematically classified and analyzed from thematic, lexical, grammatical, stylistic perspectives.

At the first stage of the study, we analyzed the Novaya Gazeta website in terms of issues covered. We found that Russia's positioning in the world (primarily the media image of the President of Russia) and issues of intercultural communication were the two dominant topics that Novaya Gazeta has covered over the past two years. At the second stage, we classified the microcontexts where euphemisms were encountered in terms of central issues. It was found that among the articles in which euphemisms were used corruption-related articles constituted the majority (39 texts), followed by articles focusing on international relations (30 texts) and terrorism and military operations (19 texts). We found that most authors of ironic texts were critical of the Russian government.

\section{AnALYSis OF THE LiBERAL Media Discourse}

Among the most detailed definitions of a discourse, its interpretation will be optimal as symbolic activity carried out in a public communicative space and possessing the necessary properties: integrity, connectedness, information density, and communicative-pragmatic orientation (Shevchenko 2012). B.Z. Demiankov (Demiankov 2002) identifies four aspects in the study of political discourse: political science, socio-psycholinguistic, individual hermeneutic, and philological. From a philological point of view, opposition discourse is seen as a kind of political discourse, characterized by a wide range of emotions, values and attitudes that more or less deny emotions, values and attitudes offered and cultivated by the authorities (Iumadilov 2013). It is this opposition that forms the ideological context of the 
studied discourse. The genesis of the opposition discourse goes back to the liberal discourse, containing a complex of ideas that were formed in the 17th and 18th centuries in Europe and since influenced the development of political, economic, cultural processes in the world. In his study of the Latin American media system I.V. Grigoriev (Grigoriev 2018) gives a historical overview of Paraguay's media. He stresses the willingness of the nation's government to improve the country's image in the eyes of the international community. As a measure towards this goal, I.V. Grigoriev refers to an agreement of intent to create a mechanism to ensure the safe work of journalists in Paraguay signed on November 28, 2016, between the government of Paraguay and UNESCO's Deputy Director for Communications and Information. This agreement involves representatives of all three branches of government pledging to work towards improving the situation with press freedom and access to information. In terms of key subjects, contemporary opposition discourse focuses on economic freedom, human rights and other liberal values, corruption, the use of national resources for the personal benefit of representatives of government, etc., (Gorshkov 2012). These themes are constantly present in a number of Russian media: Novaya Gazeta, Sobesednik, RBC and others.

In a democracy, opposition is a natural element of a political system. It operates openly; it has its own media and levers of influence on government policy; and it is one of the manifestations of political pluralism. According to D. Kheld (Kheld 2014), democracy does not imply agreement on different values - rather, it offers a way of interconnecting values and providing resolution of value conflicts to participants in an open process, subject to only certain conditions protecting the order and form of the process itself. The well-known Russian sociologist Lev Gudkov (Gudkov 2015) gives a low assessment of Russian society, stating that Russian people have a persistent resentment of government and activate negative identity mechanisms (significance of external threats, danger posed by strangers, denial or devaluation of basic values, forming the structure of national identity). Supporters of this point of view see a serious problem associated with the civilizational crisis of democracy and a skeptical attitude to its liberal form, the search for an effective model of governance that would combine the idea of democracy with the system of government in order to successfully implement public interests using effective moral mechanisms and avoiding legal risks.

There is a direct link between the oppositional character of a media outlet and the democratization of the language it uses. S. V. Davydova (Davydova 2011) argues that the process of democratization of the language (accompanying the process of democratization of society), inseparable from the influx of dubious and frankly rude vocabulary into it, including jargon, the specific language of the criminal world, etc., ultimately works to expand the boundaries of the Russian literary language. English slang or local jargon is a product of not only a certain social environment. This is often a challenge to the official (literary) language. The modern language of the media satisfies the needs of those who were not satisfied with the Russian literary language. According to B. A. Uspenskii (Uspenskii 1996), the specificity of the Russian language in this regard is especially evident in comparison with Western European languages, where such vocabulary is not taboo. The lifting of censorship in 1991 led to the fact that for more than twenty years the media were filled with obscene language. According to Y. I. Levin (Levin 1996), in the vast and heterogeneous set of obscene expressions (OE), two main classes can be distinguished. The first class consists of actual cursing, that is, expressions, the use of which is an independent speech act, directed in a certain way and endowed with swearing illocutionary force (along with perhaps others). Substitution OEs fall into the second class that do not 
form independent speech acts and, as a rule, are expressive synonyms for 'ordinary' expressions or parts of them. It is characteristic that in the 1991-2014 media texts there were obscene expressions of both the first and second classes. The author's intention was to create comic effect in almost any type of text.

According to O.S. Issers (Issers 2017) euphemisms can be attributed to one of the most dynamic spheres in the composition of any language. This domain demonstrates a historical variability of the boundaries between what is considered decent and obscene. An analysis of the role of euphemisms in linguistic dynamics was addressed by L. V. Zubova (Zubova 2014) who came to the conclusion that the role of euphemisms in the language dynamics is aggressive and destructive. The expansion of euphemisms leads to pushing neutral and terminological vocabulary out of the language. A large number of words are constantly moving into low register, which until they took on a substitution function had been neither rude nor offensive.

Content analysis of opposition media that preserved the basic features of the 1990s discourse such as critical, carnivalized interpretation of political life, did not reveal cases of using forbidden lexis; obscenities gave way to euphemisms. Mikhail Bakhtin identified permissiveness as a global feature of the phenomenon of carnivalization. Permissiveness includes informality, eccentricity, laughter, profanity, obscenity, and taboo vocabulary. According to Bakhtin (Bakhtin 1990) the pathos of change and renewal, the consciousness of cheerful relativity, the prevailing truths and powers, permeate all forms and symbols of the carnival language. It is characterized by the logic of "reverse" (a l'envers, "vice versa", "inside out", the logic of continuous movements of the top and bottom ("wheel"), faces and rear, is characterized by various types of parodies and travesties, depressions, profanities, clownish crowns and debunking. Carnival, according to Bakhtin, is a temporary holiday, which inevitably follows the tightening of the norms and laws of reality. Carnivalization means polyphony, cheerful relativity, immanence of the comic picture of the world. In this regard, carnival should not be associated with the concept of carnival exclusively in the everyday sense.

The modern interpretation of carnivalization contains the term "queering", which is understood as an alternative understanding of reality, the transformation of common social ideas and experiences, values and ideologies, models of interaction and relationships (Arpentieva 2018). Queering is an aspect of the verbal picture of the anti-world in which the author's speech behavior is perceived as anti-behavior. Anti-behavior manifests itself in shocking, destructive, antitheses to norm and order. As an opposition to norms, tastes, canons, cultural prohibitions, precepts, traditions, anti-behavior releases the energy of creative activity.

Satire dominates the quirking genre repertoire, dating back to ancient menippean satire. Just like modern satire, manippean satire implies the reduction of the level of sacredness, the predominance of negative connotations, a change in the associative sphere, in the ambiguous use of linguistic units characteristic of high language culture. According to Uspenskii (Uspenskii 1996) the taboo placed on swearing and the words associated with it does not contradict active use of these expressions as part of anti-behavior, which violates cultural prohibitions.

The opposition discourse of Novaya Gazeta follows the developments that took place in the Russian language at the turn of the century. They include active use of negative evaluation nominations, the predetermined nature of evaluations, diversity of recognizable characterizations easily recognized by the addressee, and the predominance of interpretation over the fact (Kakorina 1996). The discourse on Russian foreign and domestic policy in the 
opposition media represents a carnivalized communicative space in full compliance with all the main characteristics of postmodernism with its uncertainty, fragmentation, decanonization, impersonality, irony, and hybridization, reflecting the comic, absurd nature of events.

Speech anti-behavior releases negative emotions, being a means of achieving the main illocutionary intention to introduce into the minds of readers a feeling of unanimity with the author, being on the same emotional wave. According to Anna Wierzbicka, emotions cannot be identified without the help of words, and words belong to one particular culture and bring with them a culturally specific point of view (Wierzbicka 1996). It should be taken into account that reduced vocabulary is one of the main signs of colloquial speech, accessible, understandable and natural speech of media audiences.

Among the numerous negative evaluation reflexives, statements stand out whose illocutionary goal is to describe political abuses. It is interesting to observe the nature of perception of the apparatus of power and its conceptualization in political media texts from the point of view of cognitive linguistics and linguistics of a poetic text. The result of the influence of the poetic work is the regulation of the reader's emotional and semantic sphere, which depends on the degree of understanding and emotional "accommodation", i.e. the emergence in the reader of emotions that are similar to those of the author. We consider such linguistic phenomena in the opposition discourse as euphemization and hyperexpression from these theoretical positions. The term overexpression implies the combinatorics of expressive means in a journalistic text. Overexpression performs a compensatory function, actualizing the semantic ambiguity of euphemisms.

Euphemia acts as a way of creating a comic effect through phonetic, lexical, morphological, syntactic, and textual means. Euphemisms are words or expressions that, under certain conditions, serve to replace unwanted signs. According to B. A. Larin (Larin 1961), euphemisms are short-lived. An essential condition for the effectiveness of euphemism is the presence of "rude" or "unacceptable" language. As soon as this implied unpronounceable expression goes out of use, the euphemism loses its "ennobling" properties, as it goes into the category of "direct" names, and then requires a new substitution.

Opposition discourse is a special area of euphemization in which euphemistically labeled words do not turn into emotionally neutral ones (Krysin 1996). Euphemistic statements most often turn out to be a way of discrediting the object of criticism, as a result of which they, in essence, become dysphemisms that enhance the comic effect of the text. A satirical text is always different from texts of other styles, especially when it belongs to a poetic space.

V.P. Pavlyuchuk notes that the political thought of writers from different eras responded either to foreign political or internal circumstances, but in general, in political lyrics, in essence, there has always been one theme: freedom and independence - the independence of a country, state or human freedom within its own state. And here one cannot fail to note the fact of the ambivalence of the concept of "people", on behalf of whom a political poet invariably acts. In the foreign policy sense, the concept of "people" is always equivalent to the concept of "nation", while in the lyrics that raise social issues, "people" were the oppressed classes (Pavlyuchuk 2012). We can point to some works, which only partially touch upon the problem of interest to us (Zheltukhina 2007a; Zheltukhina 2007b). M.R. Zheltukhina argues that there is a comic dimension in political discourse as a kind of emotional-value orientation, along with cynicism, rudeness and seriousness. According to Gorshkov (Gorshkov 2006), politicians, their qualities and political activity become the subject of comic ridicule in the opposition discourse. A text would be filled with sensually-perceived images, which allows the emotional dimension of the content to prevail over the objective-logical one. He further 
writes (Gorshkov 2006) that the definition of literary texts as emotionally expressive only emphasizes the important role of expressiveness and evaluation in literary works. As for the "quantitative and qualitative" correlation of subject-logical and emotionally expressive structures in them, it is very diverse. Being the most complex linguistic unity, the text is evaluated as complex phenomena, the main components of which are considered to be information-structural and tonal (stylistic) aspects.

\section{INVECTIVE VOCABULARY AND EUPHEMISMS}

Invective vocabulary and phraseology are composed of words and expressions that, in their semantics, expressive coloring and assessment, insult the personality of the addressee, the intention of the speaker or writer to humiliate, insult, dishonor, disgrace the addressee of his speech (or object of insult) in the most derogatory, harsh, rude or cynical form. Two groups are distinguished within the invective vocabulary: literary, i.e. words and phrases related to the Russian literary language and non-literary, e.g. slang, vernacular language, dialect words and obscenities.

The first group is composed of several subgroups.

Subgroup 1 is constituted by assertive nominations of a person referring to the person's activities or behavior which are negative from the point of view of the interests of society (or its majority). When used figuratively or metaphorically, these words acquire pejorative (condemning), invective expression and a clearly negative assessment, socially recognized as an insulting or slanderous characteristic.

Subgroup 2 is formed by words and phrases, the very meaning of which, with the assertive nature of semantics, contains a negative assessment of the activity, occupations, behavior of the object, accompanied by an expressive coloring of a journalistic nature. In contrast to the words of the first subgroup, these words have no figurative use (apparently, due to the expressive coloring already present in the nominative use).

Subgroup 3 contains neutral nominations of a person by his or her profession, occupation, which in figurative meanings acquire a sharply negative assessment, usually accompanied by an expression of disapproval, contempt, etc.

Subgroup 4 includes zoomorphic metaphors, containing as a rule negative assessments of the object and a rude expression of disapproval, contempt, neglect, etc.; many of these metaphors refer to swearing (invective) vocabulary, remaining, however, within the bounds of the Russian literary language.

Subgroup 5 contains words denoting actions or qualities, properties of someone or something. Among such words are words of assertive semantics and words of appreciation, with expressive coloring. Very often, a similar characteristic of the action is transferred to the actor.

Subgroup 6 is formed by words and phrases, the very meaning of which is a negative (swearing) assessment of someone as a person, with a rather strong negative expression.

Subgroup 7 is mainly composed of phrases that appear to be euphemisms in relation to the nominations of the first subgroup. Nevertheless, in emotionally charged speech, these euphemisms are no less evaluative than the corresponding 'direct' designations of the addressee.

Subgroup 8 consists of coined formations (often built on a puns) created with the aim of offending the object of criticism and emphasizing the active rejection of their activities and actions. 
The second group of invective vocabulary and phraseology is extra-literary vocabulary and phraseology. This group includes: abusive non-literary vocabulary, most often taken from jargons and dialects; obscene mat vocabulary; rude vernacular lexis, which is part of the Russian literary language; and finally, profanities that are part of the Russian literary language.

Euphemisms should soften and veil the statement, which can be, from the point of view of the perceiving subject, negative, indecent, and unpleasant. In Zherebilo's dictionary of linguistic terms, euphemism is defined as a softer expression used in place of a rude or obscene one (Zherebilo 2010). However, in satirical text, euphemisms begin to fulfill a comic function opposite to their intended purpose (Sakhno 2006), (Vostrikova 2012). Euphemism acts as a linguistic way of creating a comic effect. Many authoritative researchers of euphemia consider the comic function as intrinsic to euphemisms: A.M. Katsev (Katsev 1976), L.P. Krysin (Krysin 1996), E.P. Senichkina (Senichkina 2006), and others. When performing a comic function euphemism at once softens the message (allows the speaker not to name culturally and ethically forbidden phenomena directly), and strengthens it, since the meaning of the phenomenon becomes even more obvious. Designed to veil information that may seem negative, unpleasant, indecent, and unethical to the addressee, euphemisms play the opposite role: they draw attention to the nominated phenomenon.

Oppositional media text is characterized by psychological and social openness (dissipation); social transcendence (the ability to go beyond the limits of everyday life into the past, future, parallel fantasy worlds, reflexivity, and responsibility. Its polemical attitude determines the choice of semantic units, the main of which are irony and colloquialism. Euphemisms, parody, language games, and ironic commentary distinguish the style of ironic media text. Following Kuznets and Skrebnev (Kuznets, Skrebnev 1960) we mean under the term 'style' the totality of the artistic means characteristic of a linguistic personality; systems of language tools and ideas peculiar to the author; a special manner of speech behavior, and finally, the emotional tonality of speech.

Any ironic text is interesting for its subtext. N.A. Fateeva (Fateeva 2001) argues that this new art, removing some of the old prohibitions of the language, requires a different perception of the text: it involves the reader in a poetic game with the author, who is sometimes deeply ironic, and as if frolic and playful, opens before his or her readers previously unknown dimensions and angles of the universe. Indeed, the very word author comes from auctor, i.e. that which expands.

Table 1 presents statistical data on the number of euphemisms replacing substandard vocabulary by subject.

Table 1 Number of euphemisms by subject

\begin{tabular}{|l|l|l|r|}
\hline$\#$ & Subject & Subgroups & Total \\
& & $1,2,3,4,5,6,7,8$ & \\
\hline 1 & Positioning of Russia & $0,1,1,1,5,28,35,48$ & 119 \\
2 & Intercultural Communication & $0,1,1,1,1,1,3,50$ & 58 \\
3 & Crime & $0,2,2,2,2,2,6,63$ & 79 \\
4 & Sports & $1,1,1,1,2,1,9,31$ & 47 \\
5 & Quality of Life & $3,4,10,4,0,0,0,0$ & 17 \\
\hline
\end{tabular}




\section{CONCLUSION}

Opposition discourse is a sphere of communicative conflict between the press and government. The inevitable consequence of this conflict is the risk-taking nature of the discourse. The recent legislation on extremism and the use of Russian made the media change their speech strategy. Journalists had to turn to euphemisms and a wide spectrum of comical means including wordplay, irony, sarcasm, and intertextuality.

The study proves that the media actively use euphemisms, forming a stable associative-emotional satirical field. In the satirical text, euphemisms add a comical twist to the statement, that is, they perform a function opposite to their purpose to soften rudeness or obscenity.

The case study of the Russian national newspaper Novaya Gazeta demonstrates that it has created a carnivalized communicative space in full compliance with all the main characteristics of postmodernism with its de-canonization, impersonality, and irony that emphasize the comic, absurd nature of events.

\section{REFERENCES}

Arpentieva M. R. (2018) "Discourses and practices of queering in modern media". Sovremennyi diskurs-analiz, 3 (2).p. 151-158.

Bakhtin M. M. (1990) Francois Rabelais's works and the folk culture of the Middle Ages and the Renaissance). $2^{\text {nd }}$ edition. Moscow: Khudozhestvennaia literatura. p.16.

Davydova S. V. (2011) The language of the media. Lingua mobilis, 2 (28). p. 93.

Demiankov V. Z. (2002) "Political discourse as a subject of political science philology." Politicheskie nauki. Politichesky diskurs: istoria $i$ sovremennye issledovania. Gerasimov V. I. \& Ilyin M. V. (eds.). Moscow: RAN INION, p.34.

Fateeva N. A. (2001) "The main trends in the development of poetic language at the end of the 20th century." Novoe literaturnoe obozrenie. 50. p. 416-434.

Garant (2019a). The Garant Legal Reference System of the Russian Federation. http://ivo.garant.ru/\#/document/12127578/paragraph/51:0). Accessed on 03.10.19

Garant (2019b). The Garant Legal Reference System of the Russian Federation. http://ivo.garant.ru/\#/document/12127578/paragraph/38010:0). Accessed on 03.10.19.

Garant (2019c). The Garant Legal Reference System of the Russian Federation. http://base.garant.ru/12140387/). Accessed on 03.10.19.

Gorshkov A. V. (2012) "Ideological rationale for the concept of 'rogue states' in theory and in practice." Probely v rossiiskom zakonodatestve. 2. p. 266-269, 117, 120.

Grigoriev I.V. (2018) "Features of the functioning of the Latin American model of media systems: a case study of Paraguayan media." Mediascope. Issue. 4. Access Mode: http://www.mediascope.ru/2486, DOI: 10.30547/mediascope.4.2018.4

Gudkov L. D. (2015) “Resentment nationalism.” Politicheskaia kontseptologiia. 4. p. 118.

Issers O. S. (2017) "Viral euphemization in the context of mass speech culture." Trudy instituta russkogo iazyka im. V.V. Vinogradova. Moldovan A. M. (ed.). Kultura russkoi rechi Series. Issue.13. Moscow: Institut russkogo iazyka im. V. V. Vinogradova RAN, p.45.

Iumadilov R. F. (2013) "The evolution of political protest: from opposition views to opposition activity." Voprosy natsionalnykh i federativnykh otnoshenii. 1(20). p.144.

Kakorina E. V. (1996) "The stylistic design of the opposition press." Russkii iazyk kontsa XX stoletiia (1985-1995). Moscow: Iazyki russkoi kultury, p. 409-426. 
Karaulov I. N. (2010) "Russian language and language personality." $7^{\text {th }}$ edition. Moscow: Izdatelstvo LKI.

Katsev A. M. (1976) "Euphemistic potential and its realization in speech." Nekotorye problemy slova i predlozheniia $v$ sovremennom angliiskom iazyke. Deeva I. M. (ed.). Gorkii: Gorkovskii pedadogicheskii institut. p. 19-35.

Kheld D. (2014) Democratic models. $3^{\text {rd }}$ edition. Moscow: ID Delo RANKhiGS. p.429.

Krysin L. P. (1996) "Euphemisms in modern Russian language." Russkii iazyk kontsa XX stoletiia (1985-1995). Zemskaia E. A. (ed.). Moscow: Iazyki russkoi kultury. p. 384-408.

Larin B. A. (1961) "On euphemisms." Problemy iazykoznaniia: Sbornik statei, posviashchennyi 75-letiiu akad. I. I. Meshchaninova. Larin B. A. (ed.). Leningrad: LGU. p.120.

Levin I. I. (1996) "On the obsessive expressions of the Russian language." Anti-mir russkoi kul'tury. Iazyk. Folklor. Literatura. Bogomolov N. A. (ed.). Moscow: Ladomir,. p. 110.

Melnik G. S., Misonzhnikov B. I. (2015) The sociolinguistic markers of extremist text." Gumanitarnyi vektor. Filologiia Series. Vostokovedenie. 4(44). p.108.

Pavliuchuk V. P. (2012) "I. Kerner's political and civic poetry." Vysshee gumanitarnoe obrazovanie XXI veka: problemy $i$ perspektivy. Materialy sedmoi mezhdunarodnoi nauchno-prakticheskoi konferentsii. Samara: Samarskii gosudarstvennyi sotsialnopedagogicheskii universitet. p.247-254.

Sakhno O. S. (2006) Phrasal nomination as a means of speech euphemization: a study of the language of Russian fiction of the $19^{\text {th }}$ and $21^{\text {st }}$ centuries. Avtoref. dis. ... kand. filol. nauk: 10.02.01. Piatigorsk.

Sepir E. (1993) Selected works in linguistics and cultural studies. Moscow: Progress.

Shevchenko A. S. (2012) Theater discourse: structure, genres, features of linguistic representation (for example, Russian, English, Buryat languages)). Avtoref. dis. kand. filol. nauk. St Petersburg.

Shveitser A. (1993) The decline and revival of culture. Moscow: Prometei.

Solganik G. I. (2005) "On the structure and the most important parameters of publicistic speech (language of the media)." Iazyk sovremennoi publitsistiki. Solganik G. I. (ed.). Moscow: Flinta, p.13-30.

Vostrikova O. V. (2012) "On the comic function of euphemisms." Vestnik Moskovskogo gorodskogo pedagogicheskogo universiteta. Seriia: Filologiia. Teoriia iazyka. Iazykovoe obrazovanie. 1. p.17-23.

Uspenskii B. A. (1996) "Mythological aspect of Russian expressive phraseology." Anti-mir russkoi kul'tury. Iazyk. Fol'klor. Literatura. Bogomolov N. A. (ed.). Moscow: Ladomir. p.9, 110 .

Wierzbicka A. (1996) Semantics, culture and cognition. Moscow: Russkie slovari.

Zharkova T. V. (2013) "Media language as an indicator of the speech culture of modern society." Nauchnye trudy SWORLD. 4. p.75-79.

Zheltukhina M. R. (2007a) "Suggestive influence in Russian, English and German linguistic cultures." Kommunikativnye tekhnologii v obrazovanii, biznese, politike $i$ prave Cheloveka: Chelovek $i$ ego diskurs. Issue 3. Moscow: IIaRAN; Volgograd: PrinTerra,. p. 201-213.

Zheltukhina M. R. (2007b) “On media discourse content.” Vestnik Luganskogo natsionalnogo pedagogicheskogo universiteta imeni Tarasa Shevchenko: Filologicheskie nauki. Chapter 1., 11(128). p. 27-40.

Zubova L. V. (2014) The role of euphemisms in language dynamics. XLIII Mezhdunarodnaia filologicheskaia nauchnaia konferentsiia. 2014. 11-16 marta. Tezisy. St Petersburg: SPbGU. p. 444 